\title{
MENINGKATKAN KELANCARAN ASI DENGAN METODE PIJAT OKSITOKSIN PADA IBU POST PARTUM
}

\author{
Nelly Indrasari* \\ *Jurusan Kebidanan Poltekkes Tanjungkarang \\ Email: nellyindrasari@yahoo.com
}

\begin{abstract}
Menurut Riset Kesehatan Dasar (Riskesdas) tahun 2018 Cakupan bayi mendapatkan ASI Eksklusif di Indonesia, di Provinsi Lampung dan di Lampung Selatan masih rendah. Rendahnya cakupan pemberian ASI Eksklusif ini tidak sinergis dengan cakupan kunjungan nifas Lampung Selatan sebesar 89\% dari target $90 \%$ secara nasional. Tujuan penelitian untuk mengetahui pengaruh pijat oksitoksin terhadap kelancaran ASI pada ibu post partum. Metode penelitian ini dengan menggunakan desain quasi eksperimen. Penelitian ini membandingkan antara kelompok yang mendapat perlakuan dan kelompok kontrol. Kelompok perlakuan diberikan intervensi pijat oksitosin \& Breastcare, serta kelompok control diberi perlakuan Breast Care. Populasi dalam penelitian ini adalah post partum dengan jumlah sampel 30 responden. Pengumpulan data dengan cara dilakukan intervensi dilakukan 2 kali sehari selama 5 hari, dilakukan pengamatan pada hari ke tiga sampai hari kelima. Data diolah dan di analisis dengan uji Anova. Hasil penilaian kelancaran ASI setelah diberi perlakuan adalah sebagai berikut: pijat oksitosin \& Breastcare rata-rata kelancaran ASI 12,87, dan kelompok kontrol berupa Breast Care rata-rata kelancaran ASI 11,73. Hasil uji statistik didapat nilai p < 0,005, yang berarti dapat disimpulkan ada perbedaan rata-rata kelancaran ASI antara yang diberikan perlakuan pijat oksitosin \& breastcare dengan kelompok yang hanya diberi perlakuan breast care saja. Dari hasil tersebut, disarankan bagi tenaga kesehatan dan bidan dapat mengajarkan dan memberikan stimulasi dengan berbagai macam cara baik secara alamiah dari lingkungan sekitar maupun di rekayasa seperti terapi breastcare dan pijat oksitosin untuk kelancaran ASI pada ibu nifas yang sudah terbukti memiliki pengaruh yang cukup baik.
\end{abstract}

Kata kunci: pijat oksitosin, breast care, kelancaran ASI

\section{LATAR BELAKANG}

Menurut laporan rikesdas 2018, secara nasional cakupan pemberian Air Susu Ibu (ASI) Eksklusif 0-5 bulan di Indonesia 37,3 sedangkan Provinsi Lampung sebesar 32,5\% beberapa tahun terakhir, menurut data Susenas cakupan ASI Eksklusif sebesar $34,3 \%$ pada tahun 2009, tahun 2010 menunjukkan bahwa baru $33,6 \%$ bayi kita mendapatkan ASI,tahun 2011 angka itu naik menjadi 42\% (Kemenkes RI, 2019).

Data Susenas 2010 menunjukkan bahwa baru $33.6 \%$ bayi di Indonesia yang mendapat ASI eksklusif, artinya masih ada sekitar $2 / 3$ bayi di Indonesia yang kurang mendapatkan ASI.

Begitu pentingnya ASI telah diketahui oleh beberapa ibu pasca melahirkan, namun tidak semua ibu mau menyusui bayinya karena berbagai alasan, seperti kesibukan pekerjaan, ASI kurang lancar, ASI tidak keluar, pengeluaran ASI terlambat (Chapman, 1999). Hal ini juga merupakan salah satu pelaksanaan dari PP no. 23 tahun 2012 tentang pemberian Air Susu Ibu Eksklusif dimana disebutkan bahwa pemberian ASI ekslusif bertujuan untuk menjamin pemenuhan hak bayi untuk mendapatkan ASI Ekslusif sejak lahir sampai batas berusia 6 (enam) bulan dengan memperhatikan pertumbuhan dan perkembangannya.

Air Susu Ibu (ASI) merupakan nutrisi alamiah bagi bayi dengan kandungan gizi paling sesuai untuk pertumbuhan optimal (Hegar, 2008). Oleh karena itu, Organisasi Kesehatan Dunia (WHO) merekomendasikan agar setiap bayi baru lahir mendapatkan ASI eksklusif selama enam bulan, namun pada sebagian ibu tidak memberikan ASI eksklusif karena alasan ASInya tidak keluar atau hanya keluar sedikit sehingga tidak memenuhi kebutuhan bayinya. UNICEF menegaskan bahwa bayi yang menggunakan susu formula memiliki kemungkinan meninggal dunia pada bulan pertama kelahirannya, dan kemungkinan bayi yang diberi susu formula 
adalah 25 kali lebih tinggi angka kematiannya daripada bayi yang disusui ibunya secara eksklusif (Selasi, 2009). Susu formula tidak memiliki kandungan yang lengkap seperti ASI, dan tidak mengandung antibody seperti yang terkandung dalam ASI.

Penelitian yang dilakukan oleh Ahluwia, Morrow, dan Hsia (2005) ditemukan bahwa ibu-ibu berhenti menyusui bayinya pada bulan pertama postpartum disebabkan karena puting lecet,kesulitan dalam melakukan perlekatan yangbenar serta persepsi mereka tentangketidakcukupan produksi ASI ibu sehingga tidak dapat memuaskan bayi. Penurunan produksi ASI pada hari-hari pertama setelah melahirkan dapat disebabkan oleh kurangnya rangsangan hormon prolaktin dan oksitosin yang sangat berperan dalam kelancaran produksi ASI. Penelitian yang dilakukan oleh Blair (2003) menunjukkan bahwa pada 95 ibu post partum yang menyusui bayinya ditemukan produksi ASInya menurun jika rangsangan hisapan bayi menurun atau berkurang. Demikian pula penelitian yang dilakukan oleh Pace (2001) menunjukkan bahwa penurunan hisapan bayi juga menurunkan stimulasi hormone prolaktin dan oksitosin.Menyusui dini di jam-jam pertama kelahiran jika tidak dapat dilakukan oleh ibuakan menyebabkan proses menyusu tertunda, maka alternatif yang dapat dilakukan adalah memerah atau memompa ASI selama 10-20 menit hingga bayi dapatmenyusu. Tindakan tersebut dapatmembantu memaksimalkan reseptor prolaktin dan meminimalkan efek sampingdari tertundanya proses menyusui oleh bayi (Evariny, 2008).

Perasaan ibu yang tidak yakin bisa memberikan ASI pada bayinya akan menyebabkan penurunan hormone oksitosin sehingga ASI tidak dapat keluar segera setelah melahirkan dan akhirnya ibu memutuskan untuk memberikan susu formula. Saat ini terapi nonfarmakologis untuk meningkatkan produksi ASI telah ada namun belum banyak diterapkan disemua pelayanan kebidanan karena keterbatasan informasi dilayanan kesehatan tentang prosedur pelaksanaan (Masadah, 2016). Salah satu upaya nonfarmakologis yang bisa dilakukan untuk merangsang hormone prolaktin dan oksitosin pada ibu setelah melahirkan adalah dengan melakukan pijat oksitosin. Hal ini sesuai dengan anjuran dari pemerintah untuk pemanfaatan alam sekitar atau "Back to Nature".

Pijat oksitosin juga merupakan salah satu solusi untuk mengatasi ketidaklancaran produksi ASI. Pijat oksitosin adalah pemijatan pada sepanjang tulang belakang (vertebrae) sampai tulang costae ke-5 sampai ke-6 dan merupakan usaha untuk merangsang hormon prolaktin dan okstosin setal melahirkan (Biancuzzo, 2003, Roesli, 2009). Pijat oksitosin ini dilakukan untuk merangsang reflek oksitosin atau refleks letdown. Selain untuk merangsang refleks letdown manfaat pijat oksitosin adalah memberikan kenyamanan pada ibu, mengurangi bengkak (engorgement), mengurangi sumbatan ASI, merangsang pelepasan hormon oksitosin, mempertahankan produksi ASI ketika ibu dan bayi sakit (Depkes RI, 2007).

Penelitian lain yang mendukung adalah hasil penelitian Suryani di Surakarta tahun 2010, untuk melihat pengaruh pijat oksitosin terhadap produksi ASI dengan indikator berat badan, frekwensi bayi BAK, frekwensi bayi menyusu dalam sehari dan lama tidur bayi setelah menyusu. Hasil penelitian menunjukkan semua bayi dilahirkan secara normal dengan berat badan bayi rata rata adalah 3070 grm , rata rata frekwensi BAK 5 kalipada hari pertama,,rata rata frekwensi menyusu bayi pada 24 jam pertama 8 kali,dan lama bayi menyusu 2.17 jam pada hari pertama.Semua indicator diatas meningkat baik pada hari ke 7 dan 14. Hasil Analisabivariat menunjukan adanya perbedaanrata rata berat badan bayi denganp value: 0.001 ,ada perbedaan frekwensi BAK yang bermakna dengan $p$ value $=0,001$ dan ada perbedaan frekuensi menyusu yang bermakna dengan $\mathrm{p}$ value $=0,001$ serta ada perbedaan lama tidur yang bermakna dengan $\mathrm{p}$ value $=0,001$. Dapatdisimpulkan bahwa ada pengaruh pijat oxytosin terhadap produksi ASI dengan indikasi berat badan bayi, frekwensi bayi menyusu, frekwensi bayi BAK dan lama bayi tidur setelah menyusu (Suryani, 2010). 
Di Provinsi Lampung, tampak bahwa cakupan pemberian ASI Ekslusif pada tahun 2011 adalah sebesar 29,24\% dengan angka target $60 \%$, sedangkan pada tahun 2012 angka cakupan tercatat sebesar $30,05 \%$ dengan target sebesar $80 \%$ data tersebut tampak bahwa cakupan ASI Ekslusif di Provinsi Lampung belum mencapai target yang ditetapkan provinsi (Dinkes Provinsi Lampung, 2015).

Cakupan pemberian ASI Ekskluasif di Lampung Selatan menetapkan target sebesar $80 \%$ dan pencapaian pemberiannya sejak tahun 2013 s.d 2015 pada tahun 2013 sebesar $42 \%$, tahun 2014 sebesar 45,5\% dan tahun 2015 sebesar 48\% (Dinkes Kabupaten Lampung Selatan, 2016).

Berdasarkan cakupan pemberian ASI tersebut masih jauh dari target yang ditetapkan Kabupaten Lampung Selatan sendiri dan juga masih jauh sekali dari target nasional sebesar $80 \%$. Rendahnya cakupan pemberian ASI Eksklusif ini tidak sinergis dengan cakupan kunjungan nifas Lampung Selatan sebesar $89 \%$ dari target $90 \%$ secara nasional.

Wawancara dilaksanakan pada $15 \mathrm{ibu}$ postpartum di Wilayah Lampung Selatan dengan menanyakan riwayat keluarnya ASI sejak hari segera setela melahirkan, diperoleh 2 orang (13\%) ASI keluar lancar saat IMD, selanjutnya meningkat $13 \%$ lagi pada hari ke-2, namun keadaan keluarnya ASI sampai dengan hari ke-3 hanya 44\% (4 orang) sehingga 56\% (6 orang) ibu mengalami ASI tidak lancar/bendungan ASI pada hari ke-6.

Hasil studi pendahuluan, breast care dilaksanakan pada salah satu PMB di Lampung Selatan teradap 3 orang ibu dengan keluhan ASI kurang lancar pada hari ke-3 (33\%), diperoleh $1 \mathrm{ibu}$ berasil lancar pada ari ke-4 dan 2 orang ibu berhasil lancar pada hari ke-7.

Pelaksanaan teknik pijat oksitosin dilakukan terhadap 3 orang ibu di PMB lain diperoleh $2 \mathrm{ibu}(66,7 \%)$ ASI lancar pada hari ke-3 dan sisanya 1 ibu lancar pada hari ke-4. Hasil observasi ini memberikan alasan peneliti untuk melihat efektivitas pijat oksitosin dibandingkan dengan breast care dalam meningkatkan kelancaran ASI pada ibu postpartum.

\section{METODE}

Metode penelitian ini menggunakan desain quasi eksperimen. Penelitian ini membandingkan antara kelompok yang mendapat perlakuan dan kelompok kontrol. Kelompok perlakuan diberikan perlakuan pijat oksitosin \& Breastcare, serta kelompok control diberi perlakuan Breast Care.

Sampel penelitian ini adalah ibu nifas dengan jumlah sampel sabanyak 15 responden untuk keolompok eksperimen dan 15 responden untuk kelompok kontrol, sehingga keseluruhan responden sejumlah 30 respoden. Agar karakteristik sampel tidak menyimpang dari populasinya, maka penentuan kriteria masing-masing kelompok sampel ditentukan dengan kriteria inklusi dan eksklusi.

Pengumpulan data dengan cara melakukan intervensi sebanyak 2 kali sehari selama 5 hari, kemudian dilakukan. pengamatan kelancaran ASI pada hari ke tiga sampai hari kelima. Selanjutnya data dinalisis menggunakan analisis statistik deskriptif dan analisis statistik dengan uji anova.

\section{HASIL}

\section{Analsis Univariat}

Tabel 1: Distribusi Kelancaran ASI pada Kelompok Intervensi dan Kontrol

\begin{tabular}{lcc}
\hline \multicolumn{1}{c}{ Kelompok } & $\mathrm{n}$ & Mean \\
\hline Intervensi & 15 & 12,87 \\
\hline Kontrol & 15 & 11,73 \\
\hline Jumlah & 30 & 12,62 \\
\hline
\end{tabular}

Berdasarkan tabel di atas terlihat bahwa rata-rata tanda kelancaran ASI yang dirasakan responden dengan jenis perlakuan yang berbeda memiliki hasil yang bervariasi yaitu setelah dilakukan intervensi dengan teknik pijat oksitosin \& Breastcare rata-rata kelancaran ASI 12,87, dan kelompok kontrol diberi intervensi breast care rata-rata kelancaran ASI 11,73. 


\section{Analisis Bivariat}

Tabel 2: Distribusi Perbedaan Kelancaran ASI pada Kelompok Intervensi dan Kelompok Kontrol

\begin{tabular}{lccccc}
\hline Kelompok & Mean & SD & SE & $\begin{array}{c}p \\
\text { value }\end{array}$ & $\mathrm{n}$ \\
\hline Intervensi & 12,87 & 1,246 & 0,322 & 0,005 & $\frac{15}{15}$ \\
\hline Kontrol & 11,73 & 1,280 & 0,330 & & 15 \\
\hline
\end{tabular}

Pada tabel di atas terlihat bahwa ratarata tanda kelancaran ASI yang dirasakan responden dengan jenis intervensi dengan teknik pijat oksitosin \& Breastcare rata-rata tanda kelancaran ASI adalah 12,87 dengan standar deviasi 1,246, sedangkan untuk kelompok kontrol diberi intervensi Breast Care rata tanda kelancaran ASI adalah 11,73 dengan standar deviasi 1,280.

Hasil uji statistik didapatkan nilai $\mathrm{p}=$ 0,005, berarti dapat disimpulkan ada perbedaan rata-rata tanda kelancaran ASI antara intervensi dengan kelompok kontrol. Dengan demikian ada pengaruh pijat oksitosin terhadap peningkatan kelancaran ASI pada ibu post partum.

\section{PEMBAHASAN}

Hasil penelitian membuktikan bahwa ada perbedaan rata-rata kelancaran ASI pada kelompok intervensi yang dilakukan pijat oksitosin dan breast care, dengan kelompok kontrol yang diberi intervensi breast care saja.

Air susu ibu (ASI) adalah suatu emulsi lemak dalam larutan protein, laktosa dan garam-garam anorganik yang disekresi oleh kelenjar mamae ibu, yang berguna sebagai makanan bagi bayinya (Soetijiningsih, 1997). ASI adalah nutrisi terbaik yang secara alami sesuai dengan fase pertumbuhan bayi yang secara khusus disesuaikan untuk bayinya sendiri (Roesli, 2002).

Ibu akan merasa menyusui mereka menjadi normal atau abnormal sesuai dengan harapan mereka menyusui normal. Jumlah ASI yang tidak mencukupi kebutuhan bayi yang sering menjadi alasan ibu menghentikan pemberian ASI atau memberikan tambahan susu formula kepada bayi (Kent, 2011).

Pada penelitian ini ditemukan rata-rata kelancaran ASI terbesar didapatkan jika dilakukan intervensi dengan teknik pijat oksitosin \& Breastcare, dan selanjutnya yaitu intervensi dengan Breastcare saja. Hasil penelitian ini membuktikan bahwa standar baku berupa Breastcare yang selama ini menjadi rujukan bukan satu-satunya perlakuan yang dapat membantu kelancaran produksi ASI pada ibu nifas.

Berdasarkan hasil analisis dapat disimpulkan bahwa responden mayoritas memiliki latar belakang Pendidikan Menengah Atas, hal itu menjadi pertimbangan bagi peneliti bahwa keberhasilan penelitian tidak luput dari latar belakang pendidikan ibu, semakin tinggi pendidikan maka akan semakin mudah ibu mengaplikasikan apa yang telah diajarkan oleh peneliti.

Usaha untuk merangsang hormon prolaktin dan oskitosin pada ibu setelah melahirkan selain dengan memeras ASI, dapat dilakukan juga dengan melakukan perawatan atau pemijatan payudara, membersihkan puting, sering-sering menyusui bayi meskipun ASI belum keluar, menyusui dini dan teratur serta pijat oksitosin (Biancuzzo, 2003; Indriyani, 2006; Yohmi \& Roesli, 2009).

Banyaknya produksi dan kelancaran ASI tidak luput juga karena umur dan kondisi psikologis ibu, sebagaimana teori yang disampaikan oleh Soetjiningsih (1997), bahwa Ibu yang cemas akan lebih sedikit mengeluarkan ASI dibandingkan dengan ibu yang tidak cemas, juga ibu yang umurnya muda lebih banyak memproduksi ASI dibandingkan dengan ibu-ibu yang sudah tua.

Disamping itu juga kebersihan personal hygiene penting untuk diperhatikan (Rustam, 2009). Perawatan Payudara pasca persalinan merupakan kelanjutan perawatan payudara semasa hamil yang mempunyai tujuan antara lain: menjaga kebersihan payudara sehingga terhindar dari infeksi, mengenyalkan puting susu, supaya tidak mudah lecet, menonjolkan puting susu, menjaga bentuk buah dada tetap bagus, mencegah terjadinya penyumbatan, dan memperbanyak produksi ASI untuk 
Hasil penelitian ini sejalan dengan teori yang menyatakan bahwa pijat oksitosin memberikan banyak manfaat dalam proses menyusui, manfaat yang dilaporkan adalah selain mengurangi stress pada ibu nifas dan mengurangi nyeri pada tulang belakang juga dapat merangsang kerja hormon oksitosin, manfaat lain dari pijat oksitosin yaitu, meningkatkan kenyamanan, meningkatkan gerak ASI kepayudara, menambah pengisian ASI ke payudara, memperlancar pengeluaran ASI, dan mempercepat proses involusi uterus.

Hasil penelitian ini juga sejalan dengan penelitian sebelumnya yang dilakukan oleh Mayasari, dkk (2017) tentang Pengaruh Pijat Oksitosin Terhadap Produksi ASI Ibu Menyusui di Kendal. Hasil penelitiannya menunjukkan bahwa produksi ASI meningkat baik pada hari ke 14, dengan hasil ada pengaruh pijat oksitosin terhadap produksi ASI di Desa Merbuh Kecamatan Singorojo Kabupaten Kendal, dengan nilai $\mathrm{p}$ value $0.000<(0,05)$.

Berdasarkan kesamaan antara hasil penelitian dengan teori dan penelitian terkait yang telah dilakukan sebelumnya, maka peneliti menyimpulkan bahwa pijat oksitosin merupakan salah satu solusi yang tepat untuk mempercepat dan memperlancar produksi dan pengeluaran ASI dengan cara pemijatan sepanjang tulang belakang. Pijat ini memberikan rasa nyaman dan rileks pada ibu setelah mengalami proses persalinan sehingga mempermudah dan meningkatkan sekresi hormon prolaktin dan oksitosin.

Karakteristik responden didominasi oleh responden yang tidak bekerja sebanyak 55 orang $(91,7 \%)$ dan responden yang bekerja hanya 5 orang $(8,3 \%)$. Sehingga peneliti menyimpulkan bahwa hal ini menjadi salah satu faktor tidak langsung yang mempengaruhi kelancaran ASI karena dengan kondisi ibu yang tidak memiliki beban pekerjaan yang cukup menyita pikiran dapat membantu ibu menjadi lebih nyaman dan relaks sehingga produksi hormon oksitosin dan prolaktin dapat lebih maksimal.

Selain untuk merangsang refleks let down manfaat pijat oksitosin juga sudah terbukti dapat memberikan kenyamanan pada ibu pasca bersalin yang rentan mengalami postpartum blues, mengurangi bengkak, mengurangi sumbatan ASI, sehingga Ibu dapat mempertahankan produksi ASI agar tetap lancar.

\section{KESIMPULAN}

Berdasarkan hasil analisis data dan pengujian hipotesis serta pembahasan hasil penelitian, maka dapt disimpukan bahwa ada pengaruh yang untuk intervensi dengan teknik pijat oksitosin dan breast care terhadap rata-rata kelancaran ASI.

Rata-rata tanda kelancaran ASI yang dirasakan responden dengan jenis perlakuan yang berbeda memiliki hasil yang bervariasi. Pada penelitian ini ditemukan rata-rata kelancaran ASI terbesar didapatkan jika dilakukan intervensi dengan teknik pijat oksitosin \& Breastcare, dan selanjutnya yaitu intervensi dengan Breastcare saja.

Berdasarkan hasil tersebut penulis menyarankan agar diberikan penjelasan kepada ibu post partum pentingnya memberikan stimulasi pada periode nifas. Selanjutnya disarankan kepada fasilitas pelayanan kesehatan agar meningkatkan peran aktif bidan dan tenaga kesehatan dalam menyampaikan informasi kesehatan tentang upaya meningkatkan kelancaran ASI pada ibu nifas dan melakukan pelatihan atau mengajarkan kepada keluarga ibu tentang teknik pijat oksitosin dikombinasi dengan breast care yang secara alamiah untuk membantu kelancaran ASI pada ibu nifas.

\section{DAFTAR PUSTAKA}

Biancuzzo, M. (2003). Breastfeeding the newborn: Clinical strategies for nurses. St. Louis: Mosby.

Chapman, DJ., and Escamilla RP. (1999). Identification of Risk Factors for Delayed onset of lactation. Journal of American Dietetic Association, 450454. 
Dinkes Provinsi Lampung. (2015). Profil Kesehatan Provinsi Lampung Tahun 2015. Bandar Lampung: Dinkes Provinsi Lampung.

Dinkes Kabupaten Lampung Selatan. (2016). Profil Kesehatan Kabupaten Lampung Selatan Tahun 2016. Bandar Lampung: Dinkes Kabpupaten Lampung Selatan.

Evariny. (2008). ASI Kisah Menyusui, Http://www. Hypno brithing.Web.id diakses tgl 14 Maret 2019.

Kemenkes RI. (2019). Laporan Riskesdas 2018. Jakarta: Balitbangkes Kemenkes RI.

Kent, JC., Prime, DK., Garbin, CP. (2011). Principles for Maintaining or Increasing Breast Milk Production, Journal of Obstertic, Gynecologic and Neonatal Nursinging, 114-121.
Mayasari, TW, dkk. (2017). Pengaruh Pijat Oksitosin Terhadap Produksi Asi Ibu Menyusui. Jurnal Keperawatan Stikes Kendal, 24-29.

Roesli. U. (2002). Mengenal ASI Eksklusif, Jakarta: Trubus Agriwidya.

Roesli. U. (2009). Panduan Praktis Menyusui. Jakarta: Pustaka Bunda.

Soetjiningsih. (1997). ASI Petunjuk untuk Tenaga Kesehatan. Jakarta: EGC.

Suryani, E \& Astuti, KEW. (2010). Pengaruh Pijat Oksitosin Terhadap Produksi ASI Ibu Postpartumdi BPM Wilayah Kabupaten Klaten. Jurnal Ilmu Kesehatan Poltekkes Surakarta, 123128.

Yohmi, E \& Roesli. U. (2009). Manajemen Laktasi. Jakarta: IDAI. 